ResearchGate

See discussions, stats, and author profiles for this publication at: https://www.researchgate.net/publication/321134943

Ganoderma lucidum Polysaccharides as An Anti-cancer Agent

Article in Anti-cancer agents in medicinal chemistry · November 2017

DOl: $10.2174 / 1871520617666171113121246$

CITATIONS

12

2 authors:

Didem Sohretoglu

Hacettepe University

55 PUBLICATIONS 266 CITATIONS

SEE PROFILE
READS

177

Some of the authors of this publication are also working on these related projects:

Project $\quad$ Polyphenols as probes of cancer cell signaling. View project

All content following this page was uploaded by Chile Huang on 18 July 2019.

The user has requested enhancement of the downloaded file.

Chile Huang Louisiana State University Health Sciences Center Shreveport 162 PUBLICATIONS 8,539 CITATIONS

SEE PROFILE 
Published in final edited form as:

Anticancer Agents Med Chem. 2018 ; 18(5): 667-674. doi:10.2174/1871520617666171113121246.

\title{
Ganoderma lucidum Polysaccharides as an anti-cancer agent
}

\author{
Didem Sohretoglu ${ }^{1,2}$ and Shile Huang ${ }^{2,3}$ \\ ${ }^{1}$ Department of Pharmacognosy, Faculty of Pharmacy, Hacettepe University, TR 06100, Ankara, \\ Turkey \\ ${ }^{2}$ Department of Biochemistry and Molecular Biology, Louisiana State University Health Sciences \\ Center, 1501 Kings Highway, Shreveport, LA 71130-3932, USA \\ ${ }^{3}$ Feist-Weiller Cancer Center, Louisiana State University Health Sciences Center, 1501 Kings \\ Highway, Shreveport, LA 71130-3932, USA
}

\begin{abstract}
The mushroom Ganoderma lucidum (G. lucidum) has been used for centuries in Asian countries to treat various diseases and to promote health and longevity. Clinical studies have shown beneficial effects of G. lucidum as an alternative adjuvant therapy in cancer patients without obvious toxicity. G. Iucidum polysaccharides (GLP) is the main bioactive component in the water soluble extracts of this mushroom. Evidence from in vitro and in vivo studies has demonstrated that GLP possesses potential anticancer activity through immunomodulatory, anti-proliferative, pro-apoptotic, antimetastatic and anti-angiogenic effects. Here, we briefly summarize these anticancer effects of GLP and the underlying mechanisms.
\end{abstract}

\section{Keywords}

Ganoderma lucidum polysaccharides; Reishi; anti-cancer; immunomodulatory; anti-proliferative; pro-apoptotic; anti-metastatic; anti-angiogenic

\section{INTRODUCTION}

Ganoderma lucidum ( $G$. lucidum) is a kind of mushroom, which belongs to Ganodermataceae family and is known as Lingzhi in China and Reishi in Japan. It has been commonly referred as the "mushroom of immortality", "mushroom of spiritual potency", and "spirit plant" [1-2]. Due to its magical medicinal properties such as tonifying effects, enhancing vital energy, and strengthening cardiac function, G. lucidum has been used as a traditional Chinese medicine for promoting good health, perpetual youth, vitality, and longevity for thousands of years [3-6].

Corresponding author: Shile Huang, PhD, Department of Biochemistry and Molecular Biology, Louisiana State University Health Sciences Center, 1501 Kings Highway, Shreveport, LA 71130-3932, USA, Phone: (318) 675-7759; Fax: (318) 675-5180; shuan1@1suhsc.edu.

CONFLICT OF INTEREST

No potential conflicts of interest were disclosed. 
G. lucidum is listed in American Herbal Pharmacopoeia and Chinese Pharmacopoeia. According to Chinese Pharmacopoeia, G. lucidum acts to restore Qi ("life energy" or "life force" in traditional Chinese medicine) ease the mind, and relieve cough and asthma, so it is recommended for the treatment of dizziness, insomnia, palpitation, and shortness of breath [7]. Modern medicinal studies have demonstrated that this mushroom possesses a broad range of bioactivities, including anti-inflammatory, anti-oxidant, anti-glycemic, anti-ulcer, anti-cancer, and immunostimulating effects [8-13]. Hence, G. lucidum has been used to treat a variety of chronic diseases such as hepatopathy, nephritis, hypertension, arthritis, migraine, insomnia, bronchitis, asthma, diabetes and cancer [6,14]. Especially, it has also been recognized as an alternative adjuvant therapy for cancer and diabetes $[11,15]$.

G. lucidum contains a wide variety of constituents such as glycoproteins, polysaccharides, triterpenoids, meroterpenoids, sesquiterpenoids, steroids, alkaloids, benzopyran derivatives, and benzoic acid derivatives $[16,17]$. It also contains some minerals, e.g. potassium, calcium, phosphorus, magnesium, selenium, iron and zinc [6]. The composition of $G$. lucidum extracts depends on whether polar or apolar solvents are used for extraction. Polysaccharides and triterpenes are the main constituents of polar and apolar extracts, respectively. It has been found that the anticancer properties of $G$. lucidum are primarily attributed to its polysaccharides and triterpenes $[6,18,19]$. G. lucidum polysaccharides $(\mathrm{GLP})$ is composed of $(1 \rightarrow 3),(1 \rightarrow 6)$ - $\alpha / \beta$-glucans, glycoproteins and water soluble heteropolysaccharides [17]. GLP executes the anti-cancer actions through inhibiting tumor growth and metastasis, as well as boosting immune function of patients, by various mechanisms, such as anti-proliferative, pro-apoptotic, anti-metastatic, anti-angiogenic, antiinflammatory, anti-oxidant, and immunomodulatory effects (Fig 1) [20-22]. This review will focus on discussing the anticancer effects of GLP and the underlying mechanisms.

\section{ANTICANCER EFFECTS OF GLP}

\subsection{Immunomodulatory effect}

Host immune surveillance plays a crucial role in recognizing and destroying not only invading pathogens but also host cells that become cancerous, so immunotherapy has become one of the major strategies for cancer prevention and treatment [23, 24]. Accumulating evidence implicates that GLP exerts the anticancer action in part by stimulating the immune function $[20,21,25]$. This is primarily attributed to the fact that GLP can activate T and B lymphocytes, macrophages, dendritic cells (DCs) and natural killer (NK) cells, which promotes proliferation of lymphocytes, enhances phagocytosis, increases production of cytokines, and augments NK cell-mediated cytotoxicity (Fig 2) [8, $14,18,25,26]$.

2.1.1. Effect of GLP on $\mathrm{T}$ lymphocytes-T lymphocytes (also known as $\mathrm{T}$ cells) are essential for cellular immunity. There are several subtypes of $\mathrm{T}$ cells with distinct functions, such as $\mathrm{T}$ helper cells, cytotoxic $\mathrm{T}$ cells, memory $\mathrm{T}$ cells, suppressor $\mathrm{T}$ cells, natural killer $\mathrm{T}$ cells, and mucosal associated invariant $T$ cells [27]. Numerous studies have suggested that GLP is an activator of T lymphocytes. It has been described that treatment with GLP significantly promotes concanavalin A (ConA)-induced mouse lymphocyte proliferation and 
IL-2 production [28]. GLP can also enhance the DNA synthesis in mouse spleen cells in a mixed lymphocyte culture by inducing the expression of DNA polymerase a [29]. GLP increases the expression of IFN- $\gamma$ in the T-lymphocytes [30] and IL-1, IL-2, and IFN- $\gamma$ in mouse spleen cells [31]. GLP increases the production of inositol triphosphate $\left(\mathrm{IP}_{3}\right)$ and diacylglycerol (DAG) in resting T cells, although it does not influence the production of $\mathrm{IP}_{3}$ and DAG in ConA-activated T cells [32], suggesting that both $\mathrm{IP}_{3} / \mathrm{Ca}^{2+}$ and DAG/ protein kinase $\mathrm{C}$ (PKC) pathways may be involved in the immunomodulatory effect of GLP on T cells. Further studies have shown that GLP can activate both PKC and protein kinase A (PKA) in murine T cells [33].

B16F10 melanoma cells can secrete a large amount of interleukin 10 (IL-10), transforming growth factor $\beta 1$ (TGF- $\beta 1$ ) and vascular endothelial growth factor (VEGF) in the cell culture medium. It has been shown that treatment with the B16F10 cell culture supernatant prevents phytohemagglutinin (PHA) from stimulating the production of perforin and granzyme B, as well as the proliferation in lymphocytes. Interestingly, addition of GLP can fully or partially antagonize the inhibitory effects of the B16F10 cell culture supernatant on lymphocytes [34]. GLP also prevents B16F10 cells from reducing the expression of CD71 and Fas ligand (FasL) in lymphocytes [35]. Furthermore, the plasma of lung cancer patients inhibits proliferation, CD69 expression, and perforin and granzyme B production in lymphocytes activated by PHA, which can also fully or partially reversed by GLP treatment [36]. GLP treatment of the co-culture of B16F10 melanoma cells and lymphocytes increases the production of CD69 (a co-stimulatory molecule for T cell activation and proliferation), FasL and interferon (IFN)- $\gamma$ in the medium [26].

2.1.2. Effect of GLP on B lymphocytes-B lymphocytes (also known as B cells) play an important role in the humoral immunity. Different from T or NK cells, B cells express B cell receptors on their cell membrane, which allow the B cell to bind a specific antigen and produce an antibody against the antigen. Besides, $\mathrm{B}$ cells also present antigen and secrete cytokines [37]. GLP can activate B cells by increasing their proliferation and differentiation [4]. It has been reported that GLP not only increases the percentage of B cells by 2.5-4 fold, but also increases the size of B cells [38]. Similarly, in vivo treatment with GLP also activates spleen and bone marrow-derived B lymphocytes from sarcoma S180 bearing mice, and induces proliferation of the B cells and production of large amounts of immunoglobulins in mice [39]. Mechanistically, GLP can induce the expression CD71 and CD25 on B cell surface, and increase the secretion of immunoglobulins by B cells, through directly stimulating the expression of $\mathrm{PKCa}$ and $\mathrm{PKC} \gamma$ in $\mathrm{B}$ cells [38].

2.1.3. Effect of GLP on DCs-DCs are important professional antigen-presenting cells, which are necessary for the initiation of primary immune response of both helper and cytotoxic T lymphocytes [40]. GLP has the ability to stimulate the maturation of normal human monocyte-derived DCs and leukemic monocyte-derived DCs [5, 8, 41]. GLP increases cell-surface expression of CD80, CD86, CD83, CD40, CD54, and human leukocyte antigen-DR (HLA-DR) [42]. It also enhances the production of IL-12 p70, IL-12 p40, and IL-10 [43]. The GLP-induced activation and maturation of human monocytederived DCs are mediated by the nuclear factor kappa-light-chain-enhancer of activated B 
cells (NF- $\mathrm{\kappa B}$ ) and p38 mitogen-activated protein kinase (MAPK) pathways [44]. GLP (0.8, 3.2 , or $12.8 \mathrm{mg} / \mathrm{ml}$ ) increases the co-expression of CD11c and I-A/I-E molecules on the surface of cultured bone morrow derived DCs [45]. It elevates mRNA expression of cytokine IL-12 p40 in DCs and increases protein production of IL-12 p40 in culture supernatants. GLP also enhances the lymphocyte proliferation of mixed lymphocyte culture induced by mature DCs [41]. Treatment of leukemic monocytic cell-lines THP-1 and U937 with GLP $(100 \mu \mathrm{g} / \mathrm{mL})$ significantly increases the expression of HLA-DR, CD40, CD80 and CD86 [8]. GLP induces the differentiation of THP-1 leukemia cells to macrophage-like cells by enhancing cell adherence, superoxide production, cell cycle arrest and expression of differentiation markers such as CD11b, CD14, CD68, matrix metalloproteinase-9 (MMP-9) and myeloperoxidase. Also, GLP-induced activation of caspases and p53 contributes to this differentiation [46].

2.1.4. Effect of GLP on macrophages-Macrophages are the "big eaters" of the immune system, which engulf and digest apoptotic cells and pathogens (called phagocytosis), and produce immune effector molecules [47]. In vivo treatment with GLP activates bone marrow-derived macrophages from sarcoma S180-bearing mice, resulting in production of immunomodulatory substances, such as IL-1 $\beta$, TNF- $\alpha$ and nitric oxide (NO) [39]. GLP increases phagocytosis of macrophages significantly, and enhances the macrophage-mediated tumor cytotoxicity. Also, GLP activates macrophages in vitro, and increases the levels of various cytokines including IL-1 $\beta$, tumor necrosis factor (TNF)- $a$, IFN- $\gamma$ and IL-6 in the culture medium [48]. GLP has been shown as an inducer of MAPKsand Syk-dependent TNF- $a$ and IL-6 secretion in murine resident peritoneal macrophages. Dectin-1 is stimulated by GLP, but toll like receptor (TLR)-4 signaling is not involved in biological activities of GLP [49]. However, this is controversial, since GLP has been found to directly bind to TLR-4, mIg of B cells, 7S ribosomal protein, and bZIP enhancer [50], and to transduce certain signalings via the TLR-4 [3]. Apart from the effects of GLP on the expression of the cytokines and chemokines mentioned above, GLP also induces the expression of inflammatory cytokine IL-1, which, in part, links to its anticancer activity. It has been described that GLP up-regulates the secretion of IL-1, and the expression of proIL-1 (precursor of IL-1) and IL-1-converting enzyme in human macrophages and murine macrophages (J774A.1). This is attributed to the activation of protein tyrosine kinase/protein kinase C/MEK1/extracellular signal-regulated kinase (ERK) and protein tyrosine kinase/ Rac1/p21-activated kinase/p38 pathways [3].

2.1.5. Effect of GLP on NK cells-NK cells, unlike cytotoxic T-cells, can recognize stressed cells in the absence of antibodies and major histocompatibility complex (MHC), allowing for a much faster immune reaction, so NK cells are critical to the innate immunity [51]. It has been shown that treatment with GLP increases the population of CD14+CD26 monocyte/macrophage, $\mathrm{CD} 83^{+} \mathrm{CD} 1 \mathrm{a}^{+} \mathrm{DCs}$, and $\mathrm{CD} 16^{+} \mathrm{CD} 56^{+} \mathrm{NK}$ cells by $2.9,2.3$, and 1.5 fold, respectively, in human umbilical cord blood mononuclear cells. Also, GLP enhances NK cell-mediated cytotoxicity by $31.7 \%$ [52]. Oral administration of G. lucidum extract increases the levels of T-helper type 1 and macrophage cytokines (IL- 6 and IFN- $\gamma$ ), and enhances the NK cell activities and phagocytosis in BALB/c mice [25, 53]. A GLP fraction binds to TLR-4 receptor and activates ERK, c-Jun N-terminal kinase (JNK) and p38 MAPK. 
GLP can stimulate the expression of IL-1, IL-6, IL-12, IFN- $\gamma$, TNF-a, granulocytemacrophage colony-stimulating factor (GM-CSF), granulocyte-colony stimulating factor (GCSF) and macrophage colony-stimulating factor (M-CSF) in mouse splenocytes [18]. In addition, a GLP fraction increases in the number of DCs as well as CD4, CD8, regulatory T, B, plasma, NK and natural killer T (NKT) cells in the spleen of mice. In vivo treatment of mice with this fraction elevates the levels of 12 cytokines and chemokines including KC (CXCL1), MCP-1 (CCL2), IL-6, MIP-1 $\beta$ (CCL3), IL-1 $\beta$, IL-12p40, IL-12p70, RANTES (CCL5), IL-1a, TNF- $a$, IL-10, and IL-13 in the serum of mice [42, 53].

G. Iucidum mitigates cyclophosphamide-induced decrease in body weight, NK activity, IFN$\gamma$ production, and cytotoxic $\mathrm{T}$ lymphocyte activity, and inhibits the abnormal increase or decrease in IL-4 level due to cyclophosphamide administration [54]. Chronic administration of $2.5 \mathrm{mg} / \mathrm{kg}$ GLP accelerates recovery of bone marrow cells, red blood cells and white blood cells, as well as splenic NK cells and NKT cells, and enhances T and B cell proliferation responses compared to the treatment with vehicle. It also augments the phagocytosis and cytotoxicity of macrophages without any obvious side effect. Thus, the low-dose GLP treatment accelerates the recovery of immunosuppressed mice from leukopenia, myelosuppression and immunosuppression, which should be beneficial to cancer chemotherapy [55].

\subsection{Anti-proliferative and pro-apoptotic effects on tumor cells}

Increasing evidence has suggested that GLP functions as an anticancer agent not only by stimulating the immune response, but also by displaying direct cytostatic and cytotoxic effects on tumor cells (Fig 3) [14]. It has been described that GLP inhibits proliferation of mouse melanoma cells (B16F10), rat adrenal medulla pheochromocytoma cells (PC12) [56, 57] and human bladder cancer cells (HUC-PC and MTC-11) [58]. GLP down-regulation of cyclin D1 is associated with the growth inhibition and cell cycle arrest in human ovarian OVCAR-3 cells [59]. Studies have also revealed that both phosphoinositide 3-kinase (PI3K)/AKT/mammalian target of rapamycin (mTOR) and MAPK signaling pathways are involved in the anticancer effect of GLP. For instance, GLP reduces the expression of some signaling molecules in the PI3K/AKT/mTOR and MAPK pathways at both gene and protein levels. Treatment of inflammatory breast cancer cells (SUM-149) with the commercial GLP (Pharmanex ReishiMax GLp ${ }^{\mathrm{TM}}$ ) down-regulates the expression of mTOR downstream effectors at early time points of treatment in vitro. Particularly, GLP reduces the level of eukaryotic initiation factor (eIF) 4G (eIF4G), increases the binding of eIF4E to eIF4Ebinding protein 1 (4E-BP1), and decreases the formation of eIF4F complex, thereby inhibiting protein synthesis [60].

Also, GLP has been found to reduce cell viability in human colon cancer cells (HCT-116 and SW 480) in a concentration-dependent manner [61, 62]. GLP can induce apoptosis by enhancing the release of lactate dehydrogenase (LDH) and increasing the level of intracellular $\mathrm{Ca}^{2+}$, leading to activation of Fas-mediated caspase, mitochondrial and JNK pathways in HCT-116 cells [61, 63]. A GLP fraction triggers apoptosis in THP-1 leukemia cells by up-regulating expression of death receptor (DR3 and DR4/5) ligands (TNF-a and 
TRAIL), resulting in death receptor oligomerization, recruitment of specialized adaptor proteins, and the activation of caspase pathway [64].

A commercial G. lucidum extract, Ganopoly®, at $10 \mathrm{mg} / \mathrm{ml}$, shows a remarkable cytotoxic effect on CaSki, SiHa, Hep3B, HepG2, HCT116, and HT29 cells [20]. Treatment with another commercial G. lucidum extract, ReishiMax GLp®, at 0.5 or $1.0 \mathrm{mg} / \mathrm{ml}$, dramatically reduces the cell number of inflammatory breast cancer cells (SUM-149) by $67 \%$ and $98 \%$, respectively, whereas treatment with ReishiMax GLp® does not alter the cell number of noncancerous mammary epithelial cells (MCF10A) at $0.5 \mathrm{mg} / \mathrm{ml}$, and only slightly (by $11 \%$ ) decreases the number of MCF10A at $1.0 \mathrm{mg} / \mathrm{ml}$ [65] suggesting the tumor selective effect of GLP. GLP induces apoptosis of SUM-149 and suppresses tumor spheroid formation, which is correlated with the reduced expression of some key proteins responsible for tumor survival and invasion such as BCL-2, BCL-xL, eIF4G, E-cadherin, MMP-9, p120-catenin and c-Myc in the cells [65].

Oral administration of $G$. lucidum extract (at a dose of $28 \mathrm{mg} / \mathrm{kg} /$ day) for 13 weeks does not obviously affect the body weight of mice, but inhibits breast SUM-149 xenograft volume and tumor weight by $58 \%$ and $45 \%$, respectively [60]. This is related to reduced expression of E-cadherin, mTOR, eIF4G, and p70 S6 kinase (S6K), and activity of ERK1/2.

Administration of GLP $(100 \mathrm{mg} / \mathrm{kg}) 24 \mathrm{~h}$ after tumor implantation with Ehrlich's ascites carcinoma cells shows 80.8 and $77.6 \%$ reduction in tumor volume and tumor mass, respectively; while administration of GLP at the same dose before tumor inoculation exhibits 79.5 and $81.2 \%$ inhibition of tumor volume and tumor mass, respectively [66]. Different administration protocols of GLP can lead to up to $60 \%$ inhibition of S180 xenografts in mice without obvious adverse effect on body weight [39, 53]. In Yoshida AH-130 ascites hepatoma cells implemented mice, administration of an aqueous extract of G. lucidum reduces the tumor weight in a dose dependent manner compared to the control group, with inhibition rates of $25 \%$ and $47 \%$ at 200 and $400 \mathrm{mg} / \mathrm{kg}$, respectively [67]. GLP significantly suppresses tumor growth in hepatoma-bearing mice associated with an increase of the ratio of regulatory $\mathrm{T}$ cell (Treg) and effector T cell (Teff). Moreover, GLP induces miR-125b expression and attenuates the inhibitory effect of Treg on Teff proliferation by increasing IL-2 secretion [68].

Of interest, it has been noticed that mice immunized with an L-fucose enriched GLP fraction is able to produce IgM antibodies specific to tumor-associated glycans, which have cytotoxicity and reduce the production of tumor-associated inflammatory mediators in murine Lewis lung carcinoma cells [69]. In addition, in vivo administration of GLP increases the Con A-induced proliferative response of splenocytes and induces anti-tumor activity against Lewis lung cancer in mice [49].

In addition, GLP can enhance the anti-cancer effects of chemotherapeutic agents. For instance, combination of GLP and chemotherapeutic agents (cisplatin and arsenic trioxide) displays synergistic cytotoxicity in human urothelial carcinoma cells including parental NTUB1; cisplatin-resistant, N/P(14); and arsenic-resistant, N/As (0.5). It has been proposed that GLP enhances the cytotoxicity of these compounds by activation of p38 MAPK, downregulation of AKT and XPA, induction of Fas, activation of caspases 3/8, up-regulation of 
$\mathrm{BAX}$ and $\mathrm{BAD}$, down-regulation of $\mathrm{Bcl}-2$ and $\mathrm{Bcl}-\mathrm{xL}$, and increase of cytochrome $\mathrm{c}$ release [70]. Besides, combination of cyclophosphamide and G. lucidum has been found to inhibit tumor growth more potently than cyclophosphamide alone in MM 46-bearing mice [54]. This is attributed to GLP's alleviation of cyclophosphamide-induced decrease in body weight, NK activity, IFN- $\gamma$ production, and cytotoxic T lymphocyte activity, and inhibition of cyclophosphamide-induced abnormal expression of IL-4.

\subsection{Anti-metastatic effect on tumor cells}

Cancer metastasis, one of the characteristics of malignant tumors, is the primary cause of death in most cancer patients. Tumor cell migration is a prerequisite for metastasis [71]. Thus, targeting tumor cell motility has received great attention for cancer therapy. Studies have shown that GLP can inhibit tumor cell motility and invasion in vitro and tumor metastasis in vivo (Fig 4). For example, GLP inhibits cell adhesion and/or motility in HCT-116 [63], human lung carcinoma PG cells [22], and MT-1 human breast carcinoma cells [72]. GLP inhibits cell adhesion in MT- 1 breast cancer cells by reducing $\beta 1$-integrin expression [72]. The water extract of G. lucidum inhibits cell motility in breast MDAMB-231 and prostate PC-3 cancer cells in a concentration-dependent manner [73]. This is associated with inhibition of constitutive activation of NF- $\mathrm{kB}$ and AP-1, reducing the expression of the urokinase-type plasminogen activator $\mathrm{UPA}$ and the $\mathrm{uPA}$ receptor (UPAR) in the cells. Besides, GLP inhibits oxidative stress-induced migration of MCF-7 cells by suppressing ERK1/2 signaling, resulting in down-regulation of c-fos expression and inhibition of NF- $\kappa B$ and AP-1 [74]. GLP also inhibits 4-aminobiphenyl-induced migration, by inducing actin polymerization and focal adhesion complex formation in human bladder cancer cells (HUC-PC and MTC-11) [58]. Reishi extract, ReishiMax GLp®, inhibits cell invasion by downregulation of MMP-9 [65]. In a Lewis lung carcinoma cell mouse xenograft model, administration of cyclophosphamide increases metastasis of the tumor cells to the lung in C57BL/6 mice, which can be effectively suppressed by pre-feeding with the G. lucidum-containing diet [54].

\subsection{Anti-angiogenic effect}

Angiogenesis refers to the formation of new blood vessels from pre-existing vessels, which plays a key role in promoting tumor growth and metastasis [75]. Thus, targeting angiogenesis has become an attractive intervention for cancer therapy. Many studies have demonstrated that GLP has the ability to inhibit angiogenesis. It has been shown that GLP suppresses VEGF overexpression and tumor angiogenesis in metastatic mouse melanoma B16F10 cells in vitro and Yoshida AH-130 ascites hepatoma xenografts in vivo [34, 67]. GLP peptide markedly reduces the microvessel formation as detected by chorioallantoic membrane assay [76]. A G. lucidum extract (standardized to $13.5 \%$ polysaccharides and $6 \%$ triterpenes) suppresses prostate-cancer dependent angiogenesis by inhibiting the secretion of VEGF and TGF- $\beta 1$. This is through by inhibiting AKT/ERK-mediated AP-1 activity [77].

GLP peptide inhibits angiogenesis by directly inhibiting cell proliferation of human umbilical cord vascular endothelial cells (HUVEC) [76]. GLP peptide can also directly induce cell death of HUVEC by reducing Bcl-2 anti-apoptotic protein expression and increase Bax pro-apoptotic protein expression. Furthermore, GLP peptide treatment 
decreases the secretion of VEGF in human lung carcinoma cells under hypoxia condition [78]. The above results suggest that GLP peptide inhibits angiogenesis through directly inhibiting cell proliferation and inducing cell death in vascular endothelial cells, as well as by indirectly suppressing VEGF production in tumor cells.

\subsection{Anti-inflammatory effect}

Chronic inflammation triggers cellular events that can promote malignant transformation of cells and carcinogenesis [79]. Several inflammatory mediators, such as TNF-a, IL-6, TGF$\beta$, and IL-10, have been shown to participate in both the initiation and progression of cancer [80]. GLP possesses anti-inflammatory effect in a dose-dependent manner. Administration of GLP $(100 \mathrm{mg} / \mathrm{kg})$ results in 58\% inhibition of inflammation, as evaluated by carrageenean-induced (acute) and formalin-induced (chronic) inflammation assays [66].

\subsection{Anti-oxidant effect}

GLP possesses potent scavenging activities against $\mathrm{O}_{2}^{-}, \mathrm{SO}, \mathrm{HO}, \mathrm{H}_{2} \mathrm{O}_{2}$, and 2,2diphenyl-1-picrylhydrazyl (DPPH) in vitro and in vivo [56, 81]. It has been shown that 5 $\mathrm{mg} / \mathrm{ml}$ of GLP extract can reduce DPPH radical strikingly within 2 minutes and completely scavenge the radical in 15 minutes [62]. GLP extract induces the superoxide dismutase (SOD), catalase, phase II detoxification enzyme NAD(P)H:quinone oxidoreductase 1 (NQO1) and glutathione S-transferase P1 (GSTP1) via the Nrf2-mediated signaling pathway in colorectal cancers in vitro [59]. GLP also enhances the activities of SOD, and glutathione peroxidase, and reduces the malonaldehyde level in vivo in a dose-dependent manner either in mice exposed to $\gamma$-irradiation or rats with cervical carcinoma [81, 82].

\subsection{Other activities related to cancer}

GLP protects mouse bone marrow from ${ }^{60} \mathrm{Co} \gamma$-irradiation, and diminishes the occurrence of micronuclei as a sign of $\gamma$-irradiation induced DNA damage in the bone marrow [82]. It has been observed that a GLP fraction possesses radio-protective activity and facilitates DNA repair, which may be attributed to its antioxidant effect [83]. Furthermore, a $G$. lucidum extract (SunRecome ${ }^{\circledR}$ ) decreases cisplatin-induced kaolin intake dose-dependently as a reflection of cisplatin's nausea and vomiting action. It also alleviates cisplatin-induced food intake reduction in rats in a dose dependent manner [84].

\section{CLINICAL STUDIES RELATED TO ANTICANCER EFFECTS OF GLP}

GLP administration increases immune responses in patients with advanced-stage cancer. In a non-randomized open clinical trial, 74 advanced colorectal cancer patients were administered GLP at a dose of $5.4 \mathrm{~g} /$ day for 12 weeks. It was found that treatment with GLP increased the mitogenic reactivity to PHA, counts of CD3, CD4, CD8 and CD56 lymphocytes, plasma concentrations of IL-2, IL-6 and IFN- $\gamma$, and activity of NK, but decreased plasma concentrations of IL-1 and TNF-a [15]. In another clinical trial, 34 advanced-stage cancer patients were given 1,800 mg Ganopoly ${ }^{\circledR}$ (GLP extract) three times daily for 12 weeks. This resulted in an increase in the mean plasma concentrations of IL-2, IL-6, and IFN- $\gamma$, and a decrease in the plasma levels of IL- 1 and TNF- $a$. The mean absolute number of CD56+ cells also increased and the number of CD3+, CD4+, or CD8+ only 
marginally increased compared to the base levels, with the CD4:CD8 T cell ratios unchanged. Furthermore, the treatment led to a significant increase in the mean NK activity compared to baselines [85]. A randomized, placebo-controlled, multi-centered study was conducted on advanced lung cancer patients with the same treatment protocol by Ganopoly®. The GLP treatment enhanced the immune parameters including total T cells, NK cells, and CD4/CD8 ratio. Moreover, the quality of life in terms of Karnofsky score was improved in approximately $65 \%$ of those patients [86].

A meta-analysis of the randomized-controlled trials evaluated the effect of G. lucidum on the long-term survival of cancer patients, tumor response, immunological system, improvement in quality of life, and adverse effects. The results showed that chemotherapy/radiotherapy combined with $G$. lucidum enhanced tumor response by 1.27 fold. G. lucidum increased host immune functions, especially the percentage of CD3, CD4, and CD8 lymphocytes. It was concluded that $G$. lucidum improves long-term survival in patients with advanced cancer. It should not be used as first-line therapy, but because of the general stimulatory effect on the host immune system and enhancement in tumor response, it can be used as an adjuvant therapy [87]. Although the number of clinical trials conducted is limited so far, it can be concluded that GLP has the advantage in enhancing the effects of conventional cancer therapy and improving immune functions of cancer patients. Undoubtedly, more evidence from properly designed randomized clinical trials on the treatment of specific types of cancer is needed.

\section{SAFETY, TOXICITY AND INTERACTIONS}

Hot water extract of $G$. lucidum administered orally $5,000 \mathrm{mg} / \mathrm{kg}$ to mice for 30 days does not affect body weight, organ weight, and hematological parameters [7]. A G. lucidum extract (equivalent to $220 \mathrm{~g} / \mathrm{kg}$ G. lucidum) does not produce any genotoxicty as chromosomal breakages or cytotoxic effects in mouse lymphocytes [88]. These data suggest that the water extract of $G$. lucidum or GLP is considerably safe in mice.

However, G. lucidum or its extract should be taken carefully, when patients receive treatment with anti-diabetics or anti-coagulants, as G. lucidum may augment the effects of these drugs, because of its blood glucose lowering and anti-coagulant effects. Similarly, patients who have gastric ulcers or active gastrointestinal bleeding, or will have operation soon should consult with their health providers before taking G. lucidum [89]. Furthermore, as G. lucidum possesses anti-hypertensive effect, it may also potentiate the effects of antihypertension drugs [90, 91]. GLP has anti-bacterial effect as well and it can increase the activity of some antibiotics (e.g. tetracycline and cefazolin) [92, 93].

\section{CONCLUSIONS}

Preclinical and clinical studies have demonstrated that GLP not only has anti-proliferative, pro-apoptotic and anti-migratory effects on cancer cells, but also possesses anti-angiogenic and immunomodulatory effects. Hence, combined use of GLP could be beneficial to cancer patients receiving conventional chemotherapy and/or radiotherapy, and help improve patient's immune function and alleviate the toxicity of conventional therapy. Moreover, 
according to literatures, it appears to be safe. However, more studies are still required to further elucidate the mechanisms of the immunomodulatory effect as well as the direct anticancer effects of GLP. Especially, more properly designed clinical trials for different patient groups are also warranted.

\section{ACKNOWLEDGEMENTS}

This work was supported by TUBITAK 2219 grant (D. Sohretoglu), National Institutes of Health (CA115414; S. Huang), and the Eastern Star Award of Louisiana State University Health Sciences Center-Shreveport (S. Huang).

\section{Abbreviations}

$\begin{array}{ll}\text { DCs } & \text { dendritic cells } \\ \text { DPPH } & \text { 2,2-diphenyl-1-picrylhydrazyl } \\ \text { GLP } & \text { Ganoderma lucidum polysaccharides } \\ \text { HUVEC } & \text { human umbilical cord vascular endothelial cells } \\ \text { IFN } & \text { interferon } \\ \text { MAPK } & \text { mitogen-activated protein kinase } \\ \text { mTOR } & \text { mammalian target of rapamycin } \\ \text { NF- } x \text { B } & \text { nuclear factor kappa-light-chain-enhancer of activated B cells } \\ \text { SOD } & \text { superoxide dismutase } \\ \text { TNF } & \text { tumor necrosis factor } \\ \text { VEGF } & \text { vascular endothelial growth factor }\end{array}$

\section{REFERENCES}

[1]. Huang KC The Pharmacology of Chinese Herbs, 2nd ed.; CRC Press: Boca Raton, 1999.

[2]. Babu PD; Subhasree RS The Sacred Mushroom “Reishi”-A Review. American-Eurasian J. Botany, 2008, 1, 107-110.

[3]. Hsu HY; Hua KF; Lin CC; Lin CH; Hsu J; Wong CH Extract of Reishi polysaccharides induces cytokine expression via TLR4-modulated protein kinase signaling pathways. J. Immunol, 2004, 173, 5989-5999. [PubMed: 15528333]

[4]. Lin Z-B Cellular and Molecular Mechanisms of Immuno-modulation by Ganoderma lucidum. J. Pharmacol. Sci, 2005, 99, 144-153. [PubMed: 16230843]

[5]. Sanodiya BS; Thakur GS; Baghel RK; Prasad GB; Bisen PS Ganoderma lucidum: a potent pharmacological macrofungus. Curr. Pharm. Biotechnol, 2009; 10, 717-742. [PubMed: 19939212]

[6]. Wachtel-Galor S; Yuen J: Buswell JA; Benzie IFF Ganoderma lucidum (Lingzhi or Reishi): A Medicinal Mushroom. In: Herbal Medicine: Biomolecular and Clinical Aspects; Benzie IFF; Wachtel-Galor S Eds; CRC Press/Taylor \& Francis: Boca Raton (FL), 2011.

[7]. Upton R Reishi Mushroom Ganoderma lucidum In American Herbal Pharmacopea 2006.

[8]. Chan WK; Cheung CC; Law HK; Lau YL; Chan GC Ganoderma lucidum polysaccharides can induce human monocytic leukemia cells into dendritic cells with immuno-stimulatory function. J. Hematol. Oncol, 2008, 21, 9. 
[9]. Ho YW; Yeung JS; Chiu PK; Tang WM; Lin ZB; Man RY; Lau CS Ganoderma lucidum polysaccharide peptide reduced the production of proinflammatory cytokines in activated rheumatoid synovial fibroblast. Mol. Cell. Biochem, 2007, 301, 173-179. [PubMed: 17219061]

[10]. Lee JM; Kwon H; Jeong H Inhibition of lipid peroxidation and oxidative DNA damage by Ganoderma lucidum. Phytother. Res, 2001, 15, 245-249. [PubMed: 11351361]

[11]. Ma H-T; Hsieh J-F; Chen S-T Anti-diabetic effects of Ganoderma lucidum. Phytochemistry, 2015, 114, 109-113. [PubMed: 25790910]

[12]. Saltarelli R; Ceccaroli P; Iotti M; Zambonelli A; Buffalini M; Casadei L; Luciana Vallorani L; Stocchi V Biochemical characterisation and antioxidant activity of mycelium of Ganoderma lucidum from Central Italy. Food Chem, 2009, 116, 143-151.

[13]. Yuen JW; Gohel MD The dual roles of Ganoderma antioxidants on urothelial cell DNA under carcinogenic attack. J. Ethnopharmacol, 2008, 118, 324-330. [PubMed: 18550308]

[14]. Kladar NV; Gavarić NS; Božin NB Ganoderma: insights into anticancer effects. Eur. J. Cancer Prev, 2016, 25, 462-471. [PubMed: 26317382]

[15]. Chen X; Hu ZP; Yang XX; Huang M; Gao Y; Tang W; Chan SY; Dai X; Ye J; Ho PC; Duan W; Yang HY; Zhu YZ; Zhou SF Monitoring of immune responses to a herbal immuno-modulator in patients with advanced colorectal cancer. Int. Immunopharmacol, 2006, 6, 499-508. [PubMed: 16428086]

[16]. Baby S; Johnson AJ; Govindan B Secondary metabolites from Ganoderma. Phytochemistry, 2015, 114, 66-101. [PubMed: 25975187]

[17]. Nie S; Zhang H; Li W; Xie M Current development of polysaccharides from Ganoderma: isolation, structure and bioactivities. Bioact. Carbohydr. Dietary Fibre, 2013, 1, 10-20.

[18]. Chen HS, Tsai YF; Lin S, Lin CC; Khoo KH; Lin CH, Wong CH Studies on the immunomodulating and anti-tumor activities of Ganoderma lucidum (Reishi) polysaccharides. Bioorg. Med. Chem, 2004, 12, 5595-5601. [PubMed: 15465337]

[19]. Wu GS; Guo JJ; Bao JL; Li XW; Chen XP; Lu JJ; Wang YT. Anti-cancer properties of triterpenoids isolated from Ganoderma lucidum - a review. Expert Opin. Investig. Drugs, 2013, 22, 981-992.

[20]. Gao Y; Tang W; Dai X; Gao H; Chen G; Ye J; Chan E; Koh HL; Li X; W.; Zhou S Antitumor activity and underlying mechanisms of ganopoly, the refined polysaccharides extracted from Ganoderma lucidum, in mice. Immunol. Invest, 2005, 34, 171-198. [PubMed: 15921158]

[21]. Lin ZB; Zhang HN Anti-tumor and immunoregulatory activities of Ganoderma lucidum and its possible mechanisms. Acta Pharmacol. Sin, 2004, 25(11), 1387-1395. [PubMed: 15525457]

[22]. Weng C-J; Yen G-C The in vitro and in vivo experimental evidences disclose the chemopreventive effects of Ganoderma lucidum on cancer invasion and metastasis. Clin. Exp. Metastasis, 2010, 27, 361-369. [PubMed: 20461449]

[23]. Vanneman M; Dranoff G Combining immunotherapy and targeted therapies in cancer treatment. Nat. Rev. Cancer, 2012, 12, 237-251. [PubMed: 22437869]

[24]. Sharma P; Allison JP Immune checkpoint targeting in cancer therapy: toward combination strategies with curative potential. Cell, 2015, 161, 205-214. [PubMed: 25860605]

[25]. Chang YH; Yang JS; Yang JL; Wu CL; Chang SJ; Lu KW, Kuo CL; Hsia TC; Chung JG Gandoderma lucidum extract promotes immune responses in normal BALB/c mice In vivo. In vivo, 2009, 23, 755-760. [PubMed: 19779111]

[26]. Sun LX; Lin ZB; Li XJ; Li M; Lu J; Duan XS; Ge ZH; Song YX; Xing EH; Li WD. Promoting effects of Ganoderma lucidum polysaccharides on B16F10 cells to activate lymphocytes. Basic Clin. Pharmacol. Toxicol, 2011, 108, 149-154. [PubMed: 20964805]

[27]. Golubovskaya V; Wu L Different Subsets of T Cells, Memory, Effector Functions, and CAR-T Immunotherapy. Cancers (Basel), 2016, 8, 36.

[28]. Xia D; Lin ZB; Li RZ; He YQ Effects of Ganoderma polysaccharides on immune function in mice. J. Beijing Med. Univ, 1989, 21, 533-537.

[29]. Lei LS; Lin ZB Effects of Ganoderma polysaccharides on the activity of DNA polymerase a in spleen cells stimulated by alloantigents in mice in vitro. J. Beijing Med. Univ, 1991, 23, 329333. 
[30]. Zhang QH; Lin ZB Effect of Ganoderma lucidum polysaccharides B on TNFa and INF $\gamma$ production and their mRNA expression. J. Beijing Med. Univ, 1999, 31, 179-183.

[31]. Wang YY; Khoo KH; Chen ST; Lin CC; Wonga CH; Lina CH Studies on the immunomodulating and antitumor activities of Ganoderma lucidum (reishi) polysaccharides: functional and proteomic analyses of a fucose-containing glycoprotein fraction responsible for the activities. Bioorg. Med. Chem, 2002, 10, 1057-1062. [PubMed: 11836115]

[32]. Li MC; Lei LS; Wang QB; Liang DS; Xu ZM; Yang SQ, Sun LS Effects of Ganoderma lucidum polysaccharides on inositol triphosphate and diacylglycerol in murine T cells. Chin. Pharm. J, 2001, 36, 526-528.

[33]. Li MC; Liang DS; Xu ZM; Lei LS; Wang QB; Yang SQ; Sun LS Effects of Ganoderma polysaccharides on PKC and PKA Activities in Murine T Cells. China Pharmacy, 2001, 12, 7879.

[34]. Sun LX; Lin ZB; Duan XS; Lu J; Ge ZH; Li XJ; Li M; Xing EH; Jia J; Lan TF; Li WD Ganoderma lucidum polysaccharides antagonize the suppression on lymphocytes induced by culture supernatants of B16F10 melanoma cells. J. Pharm. Pharmacol, 2011, 63, 725-735. [PubMed: 21492175]

[35]. Sun LX; Lin ZB; Duan XS; Lu J; Ge ZH; Li M; Xing EH; Lan TF; Jiang MM; Yang N; Li WD Ganoderma lucidum polysaccharides counteract inhibition on CD71 and FasL expression by culture supernatant of B16F10 cells upon lymphocyte activation. Exp. Ther. Med, 2013, 5, 11171122. [PubMed: 23596479]

[36]. Sun LX; Li WD; Lin ZB; Duan XS; Li XF; Yang N; Lan TF; Li M; Sun Y; Yu M; Lu J Protection against lung cancer patient plasma-induced lymphocyte suppression by Ganoderma lucidum polysaccharides. Cell. Physiol. Biochem, 2014, 33, 289-299. [PubMed: 24525691]

[37]. Hoffman W; Lakkis FG; Chalasani G B Cells, Antibodies, and More. Clin. J. Am. Soc. Nephrol, 2016, 11, 137-154.

[38]. Zhang J; Tang Q; Zimmerman-Kordmann M; Reutter W; Fan H Activation of B lymphocytes by GLIS, a bioactive proteoglycan from Ganoderma lucidum. Life Sci, 2002, 71, 623-638. [PubMed: 12072151]

[39]. Zhang J; Tang Q; Zhou C; Jia W; Da Silva L; Nguyen LD; Reutter W; Fan H GLIS, a bioactive proteoglycan fraction from Ganoderma lucidum, displays anti-tumour activity by increasing both humoral and cellular immune response. Life Sci, 2010, 87, 628-637. [PubMed: 20888840]

[40]. Banchereau J; Steinman RM Dendritic cells and the control of immunity. Nature, 1998, 392, 245-252. [PubMed: 9521319]

[41]. Cao LZ; Lin ZB Regulation on maturation and function of dendritic cells by Ganoderma lucidum polysaccharides. Immunol. Lett, 2002, 83, 163-169. [PubMed: 12095706]

[42]. Lai CY; Hung JT; Lin HH; Yu AL; Chen SH; Tsai YC; Shao LE; Yang WB; Yu J Immunomodulatory and adjuvant activities of a polysaccharide extract of Ganoderma lucidum in vivo and in vitro. Vaccine, 2010, 28, 4945-4954. [PubMed: 20653103]

[43]. Jan RH; Lin TY; Hsu YC; Lee SS; Lo SY; Chang M; Chen LK; Lin YL Immuno-modulatory activity of Ganoderma lucidum-derived polysacharide on human monocytoid dendritic cells pulsed with Der p 1 allergen. BMC Immunol, 2011, 12, 31. [PubMed: 21612588]

[44]. Lin YL; Liang YC, Lee SS, Chiang BL Polysaccharide purified from Ganoderma lucidum induced activation and maturation of human monocyte-derived dendritic cells by the NFxB and p38 mitogen-activated protein kinase pathways. J. Leukoc. Biol, 2005, 78, 533-543. [PubMed: 15894585]

[45]. Cao LZ; Lin ZB Regulation on maturation and function of dendritic cells by Ganoderma lucidum polysaccharides. Immunol Lett, 2002, 83, 163-169. [PubMed: 12095706]

[46]. Hsu JW; Huang HC; Chen ST; Wong CH; Juan HF Ganoderma lucidum Polysaccharides Induce Macrophage-Like Differentiation in Human Leukemia THP-1 Cells via Caspase and p53 Activation. Evid. Based Complement. Alternat. Med, 2011, 2011, 358717. [PubMed: 19696196]

[47]. Elhelu MA The role of macrophages in immunology. J. Natl. Med. Assoc, 1983, 75, 314-317. [PubMed: 6343621] 
[48]. Wang SY; Hsu ML; Hsu HC; Tzeng CH; Lee SS; Shiao MS; Ho CK The anti-tumor effect of Ganoderma lucidum is mediated by cytokines released from activated macrophages and $\mathrm{T}$ lymphocytes. Int. J. Cancer, 1997, 70, 699-705. [PubMed: 9096652]

[49]. Guo L; Xie J; Ruan Y; Zhou L; Zhu H; Yun X; Jiang Y; Lu L; Chen K; Min Z; Wen Y; Gu J Characterization and immunostimulatory activity of a polysaccharide from the spores of Ganoderma lucidum. Int. Immunopharmacol, 2009, 9, 1175-1182. [PubMed: 19540939]

[50]. Shao BM; Dai H; Xu W; Lin ZB; Gao XM Immune receptors for polysaccharides from Ganoderma lucidum. Biochem. Biophys. Res. Commun, 2004, 323, 133-141. [PubMed: 15351712]

[51]. Altfeld M; Fadda L; Frleta D; Bhardwaj N DCs and NK cells: critical effectors in the immune response to HIV-1. Nat. Rev. Immunol, 2011, 11, 176-186. [PubMed: 21350578]

[52]. Chien CM; Cheng JL; Chang WT; Tien MH; Tsao CM; Chang YH; Chang HY; Hsieh JF; Wong $\mathrm{CH}$; Chen ST Polysaccharides of Ganoderma lucidum alter cell immunophenotypic expression and enhance CD56+ NK-cell cytotoxicity in cord blood. Bioorg. Med. Chem, 2004, 12, 56035609. [PubMed: 15465338]

[53]. Wang PY; Zhu XL; Lin ZB Antitumor and Immunomodulatory Effects of Polysaccharides from Broken-Spore of Ganoderma lucidum. Front. Pharmacol, 2012, 3, 135. [PubMed: 22811667]

[54]. Nonaka Y; Ishibashi H, Nakai M, Shibata H, Kiso Y, Abe S Effects of the antlered form of Ganoderma lucidum on tumor growth and metastasis in cyclophosphamide-treated mice. Biosci. Biotechnol. Biochem, 2008, 72, 1399-1408. [PubMed: 18540114]

[55]. Zhu XL; Chen AF; Lin ZB Ganoderma lucidum polysaccharides enhance the function of immunological effector cells in immunosuppressed mice. J. Ethnopharmacol, 2007, 111, 219226. [PubMed: 17182202]

[56]. Ma C-W; Feng M; Zhai X; Hu M; You L; Luo W; Zhao M Optimization for the extraction of polysaccharides from Ganoderma lucidum and their antioxidant and antiproliferative activities. J. Taiwan Inst. Chem. Eng, 2013, 44, 886-894.

[57]. Man Q The inhibition effect on mouse melanoma cells train by Ganoderma lucidum polysaccharides in vitro. Hebei Med, 2009, 15, 400-402.

[58]. Lu QY; Jin YS; Zhang Q; Zhang Z; Heber D; Go VL; Li FP; Rao JY Ganoderma lucidum extracts inhibit growth and induce actin polymerization in bladder cancer cells in vitro. Cancer Lett, 2004, 216, 9-20. [PubMed: 15500944]

[59]. Hsieh TC; Wu JM Suppression of proliferation and oxidative stress by extracts of Ganoderma lucidum in the ovarian cancer cell line OVCAR-3. Int. J. Mol. Med, 2011, 28, 1065-1069. [PubMed: 21887458]

[60]. Suarez-Arroyo IJ; Rosario-Acevedo R; Aguilar-Perez A; Clemente PL; Cubano LA; Serrano J; Schneider RJ; Martínez-Montemayor MM. Anti-tumor effects of Ganoderma lucidum (reishi) in inflammatory breast cancer in in vivo and in vitro models. PLoS One, 2013, 8, e57431. [PubMed: 23468988]

[61]. Liang Z; Guo YT; Yi YJ; Wang RC; Hu QL; Xiong XY Ganoderma lucidum Polysaccharides Target a Fas/Caspase Dependent Pathway to Induce Apoptosis in Human Colon Cancer Cells. Asian Pac. J. Cancer Prev, 2014, 15, 3981-3986. [PubMed: 24935584]

[62]. Xie JT, Wang CZ; Wicks S; Yin JJ; Kong J; Li J; Li YC; Yuan CS Ganoderma lucidum extract inhibits proliferation of SW 480 human colorectal cancer cells. Exp. Oncol, 2006, 28, 25-29. [PubMed: 16614703]

[63]. Liang Z; Yi Y; Guo Y; Wang R; Hu Q; Xiong X Chemical characterization and antitumor activities of polysaccharide extracted from Ganoderma lucidum. Int. J. Mol. Sci, 2014, 15, 91039116. [PubMed: 24857920]

[64]. Cheng KC; Huang HC; Chen JH; Hsu JW; Cheng HC; Ou CH; Yang WB; Chen ST; Wong CH; Juan HF Ganoderma lucidum polysaccharides in human monocytic leukemia cells: from gene expression to network. BMC Genomics, 2007, 8, 411. [PubMed: 17996095]

[65]. Martínez-Montemayor MM, Acevedo RR, Otero-Franqui E, Cubano LA, Dharmawardhane SF Ganoderma lucidum (Reishi) inhibits cancer cell growth and expression of key molecules in inflammatory breast cancer. Nutr. Cancer, 2011, 63, 1085-1094. [PubMed: 21888505] 
[66]. Joseph S; Sabulal B; George V; Antony KR; Janardhanan KK Antitumor and anti-inflammatory activities of polysaccharides isolated from Ganoderma lucidum. Acta Pharm, 2011, 61, 335-342. [PubMed: 21945912]

[67]. Wu X; Guan H; Li J; Guo J; Hou B Evaluation of antitumour action of Ganoderma lucidum extract in hepatocarcinoma mice. Afr. J. Pharm. Pharmacol, 2012, 6, 2884-2887.

[68]. Li A; Shuai X; Jia Z; Li H; Liang X; Su D; Guo W Ganoderma lucidum polysaccharide extract inhibits hepatocellular carcinoma growth by downregulating regulatory $\mathrm{T}$ cells accumulation and function by inducing microRNA-125b. J. Transl. Med, 2015, 13, 100. [PubMed: 25889022]

[69]. Liao SF; Liang CH; Ho MY; Hsu TL; Tsai TI; Hsieh YS; Tsai CM; Li ST; Cheng YY; Tsao SM; Lin TY; Lin ZY; Yang WB; Ren CT; Lin KI; Khoo KH; Lin CH; Hsu HY; Wu CY; Wong CH. Immunization of fucose-containing polysaccharides from Reishi mushroom induces antibodies to tumor-associated Globo H-series epitopes. Proc. Natl. Acad. Sci. U. S. A, 2013, 110, 1380913814. [PubMed: 23908400]

[70]. Huang CY; Chen JY; Wu JE; Pu YS; Liu GY; Pan MH; Huang YT; Huang AM; Hwang CC; Chung SJ; Hour TC. Ling-Zhi polysaccharides potentiate cytotoxic effects of anticancer drugs against drug-resistant urothelial carcinoma cells. J. Agric. Food Chem, 2010, 58, 8798-8805. [PubMed: 20681668]

[71]. Mehlen P; Puisieux A Metastasis: a question of life or death. Nat. Rev. Cancer, 2006, 6, 449-458. [PubMed: 16723991]

[72]. Wu Q-P; Xie Y-Z; Li S-Z; La Pierre DL; Deng Z; Chen Q; Li C; Zhang Z; Guo J; Wong C-KA; Lee DY; Yee A; Yang BB Tumour cell adhesion and integrin expression affected by Ganoderma lucidum. Enzyme Microb, 2006, 40, 32-41.

[73]. Sliva D; Labarrere C; Slivova V; Sedlak M; Lloyd FP Jr; Ho NW Ganoderma lucidum suppresses motility of highly invasive breast and prostate cancer cells. Biochem. Biophys. Res. Commun, 2002, 298, 603-612. [PubMed: 12408995]

[74]. Thyagarajan A; Jiang J; Hopf A; Adamec J; Sliva D Inhibition of oxidative stress-induced invasiveness of cancer cells by Ganoderma lucidum is mediated through the suppression of interleukin-8 secretion. Int. J. Mol. Med, 2006, 18(4), 657-664. [PubMed: 16964420]

[75]. Ucuzian AA; Gassman AA; East AT; Greisler HP Molecular mediators of angiogenesis. J. Burn Care Res, 2010, 31, 158-175. [PubMed: 20061852]

[76]. Cao LZ; Lin ZB Antitumor and anti-angiogenic activity of Ganoderma lucidum polysaccharides peptide. Acta Pharmacol. Sin, 2004, 25, 833-838. [PubMed: 15169641]

[77]. Stanley G; Harvey K; Slivova V; Jiang J; Sliva D Ganoderma lucidum suppresses angiogenesis through the inhibition of secretion of VEGF and TGF- $\beta 1$ from prostate cancer cells. Biochem. Biophys. Res. Commun, 2005, 330, 46-52. [PubMed: 15781230]

[78]. Cao LZ; Lin ZB Ganoderma lucidum polysaccharides peptide inhibits the growth of vascular endothelial cell and the induction of VEGF in human lung cancer cell. Life Sci, 2006, 78, 14571463. [PubMed: 16269156]

[79]. Lu H; Ouyang W; Huang C Inflammation, a key event in cancer development. Mol. Cancer Res, 2006, 4, 221-233. [PubMed: 16603636]

[80]. Shalapour S; Karin M Immunity, inflammation, and cancer: an eternal fight between good and evil. J. Clin. Invest, 2015, 125, 3347-3355. [PubMed: 26325032]

[81]. XiaoPing C; Yan C; ShuiBing L; YouGuo C; JianYun L; LanPing L Free radical scavenging of Ganoderma lucidum polysaccharides and its effect on antioxidant enzymes and immunity activities in cervical carcinoma rats. Carbohydr. Polym, 2009, 77, 389-393.

[82]. Zhao W; Jiang X; Deng W; Lai Y; Wu M; Zhang Z Antioxidant activities of Ganoderma lucidum polysaccharides and their role on DNA damage in mice induced by cobalt-60 gamma-irradiation. Food Chem. Toxicol, 2012, 50, 303-309. [PubMed: 22079311]

[83]. Pillai TG; Maurya DK; Salvi VP; Janardhanan KK; Nair CK Fungal beta glucan protects radiation induced DNA damage in human lymphocytes. Ann. Transl. Med, 2014, 2, 13. [PubMed: 25332989]

[84]. Wang CZ; Basila D; Aung HH; Mehendale SR; Chang WT; McEntee E; Guan X; Yuan CS. Effects of Ganoderma lucidum extract on chemotherapy-induced nausea and vomiting in a rat model. Am. J. Chin. Med, 2005, 33, 807-815. [PubMed: 16265993] 
[85]. Gao Y; Zhou S; Jiang W; Huang M; Dai X Effects of Ganopoly (A Ganoderma lucidum Polysaccharide Extract) on the Immune Functions in Advanced-Stage Cancer Patients. Immunol. Invest, 2003, 32, 201-215. [PubMed: 12916709]

[86]. Gao Y; Dai X; Chen G; Ye J; Zhou S A randomized, placebo-controlled, multicenter study of Ganoderma lucidum (W. Curt.:Fr.) Lloyd (Aphyllophoromycetideae) polysaccharides (Ganopoly) in patients with advanced lung cancer. Int. J. Med. Mushrooms, 2003, 5, 369-382.

[87]. Jin X; Ruiz Beguerie J; Sze DM; Chan GC Ganoderma lucidum (Reishi mushroom) for cancer treatment. Cochrane Database Syst. Rev, 2012, 6, CD007731.

[88]. Chiu SW, Wang ZM; Leung TM; Moore D Nutritional value of Ganoderma extract and assessment of its genotoxicity and antigenotoxicity using comet assays of mouse lymphocytes. Food Chem. Toxicol, 2000, 38, 173-178. [PubMed: 10717357]

[89]. Ulbricht C; Abrams TR; Bent S; Boon H; Costa D; Dacey C; Guilford J; Giese N; Serrano G; Hackman DA; Scully L; Rusie E; Shaffer M; Varghese M; Vijarian N; Weisnner W; Welch S; Wong D; Woods J Reishi Mushroom (Ganoderma lucidum): Systematic Review by the Natural Standard Research Collaboration. J. Soc. Integr. Oncol, 2010, 8, 148-159.

[90]. Lee SY; Rhee HM Cardiovascular effects of mycelium extract of Ganoderma lucidum: inhibition of sympathetic outflow as a mechanism of its hypotensive action. Chem. Pharm. Bull, 1990, 38, 1359-1364. [PubMed: 2393962]

[91]. Tran HB; Yamamoto A; Matsumoto S; Ito H; Igami K; Miyazaki T; Kondo R; Shimizu K Hypotensive effects and angiotensin-converting enzyme inhibitory peptides of reishi (Ganoderma lingzhi) auto-digested extract. Molecules, 2014, 19, 13473-1385. [PubMed: 25178067]

[92]. Yoon SY; Eo SK; Kim YS; Lee CK; Han SS. Antimicrobial activity of Ganoderma lucidum extract alone and in combination with some antibiotics. Arch. Pharm. Res, 1994, 17, 438-442. [PubMed: 10319155]

[93]. Karwa A; Gaikwad S; Rai MK Mycosynthesis of silver nanoparticles using Lingzhi or Reishi medicinal mushroom, Ganoderma lucidum (W. Curt.:Fr.) P. Karst. and their role as antimicrobials and antibiotic activity enhancers. Int. J. Med. Mushrooms, 2011, 13, 483-491. [PubMed: 22324414] 


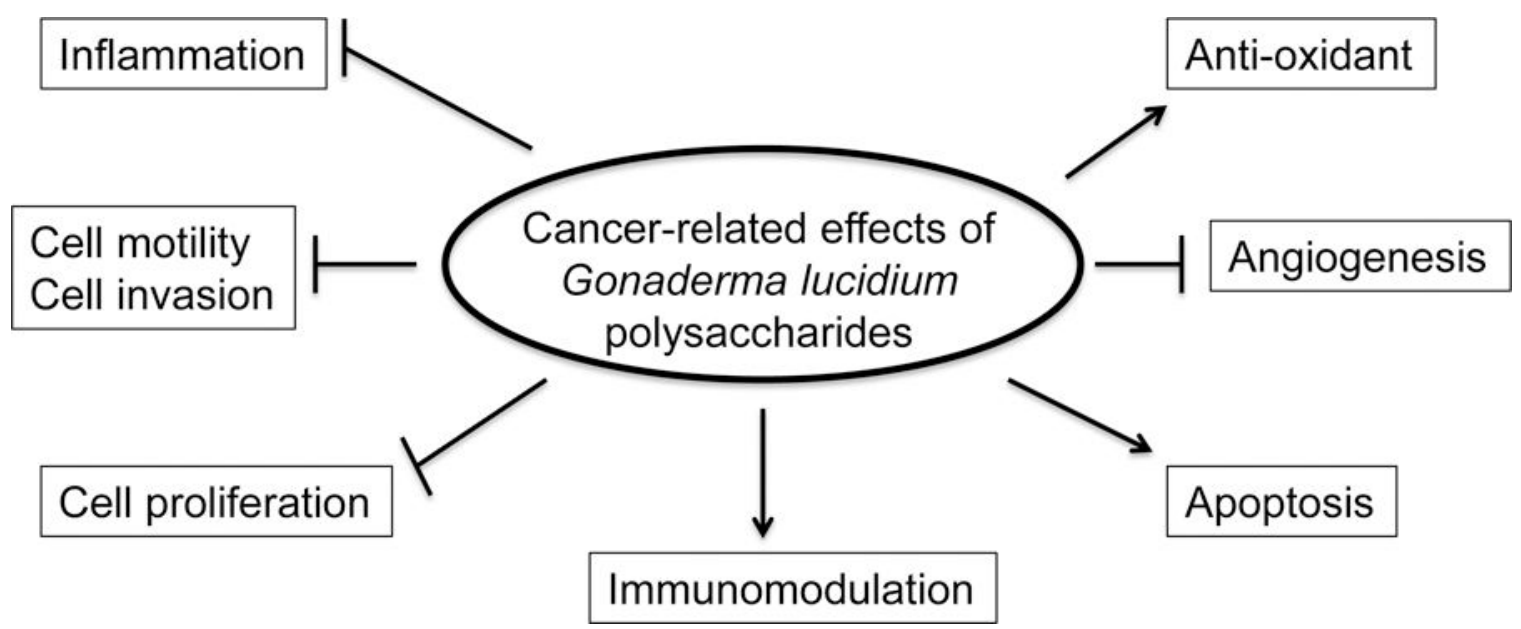

Fig 1.

Cancer-related effects of Gonaderma lucidium polysaccharides. Arrows represent activation, whereas bars represent inhibition. 


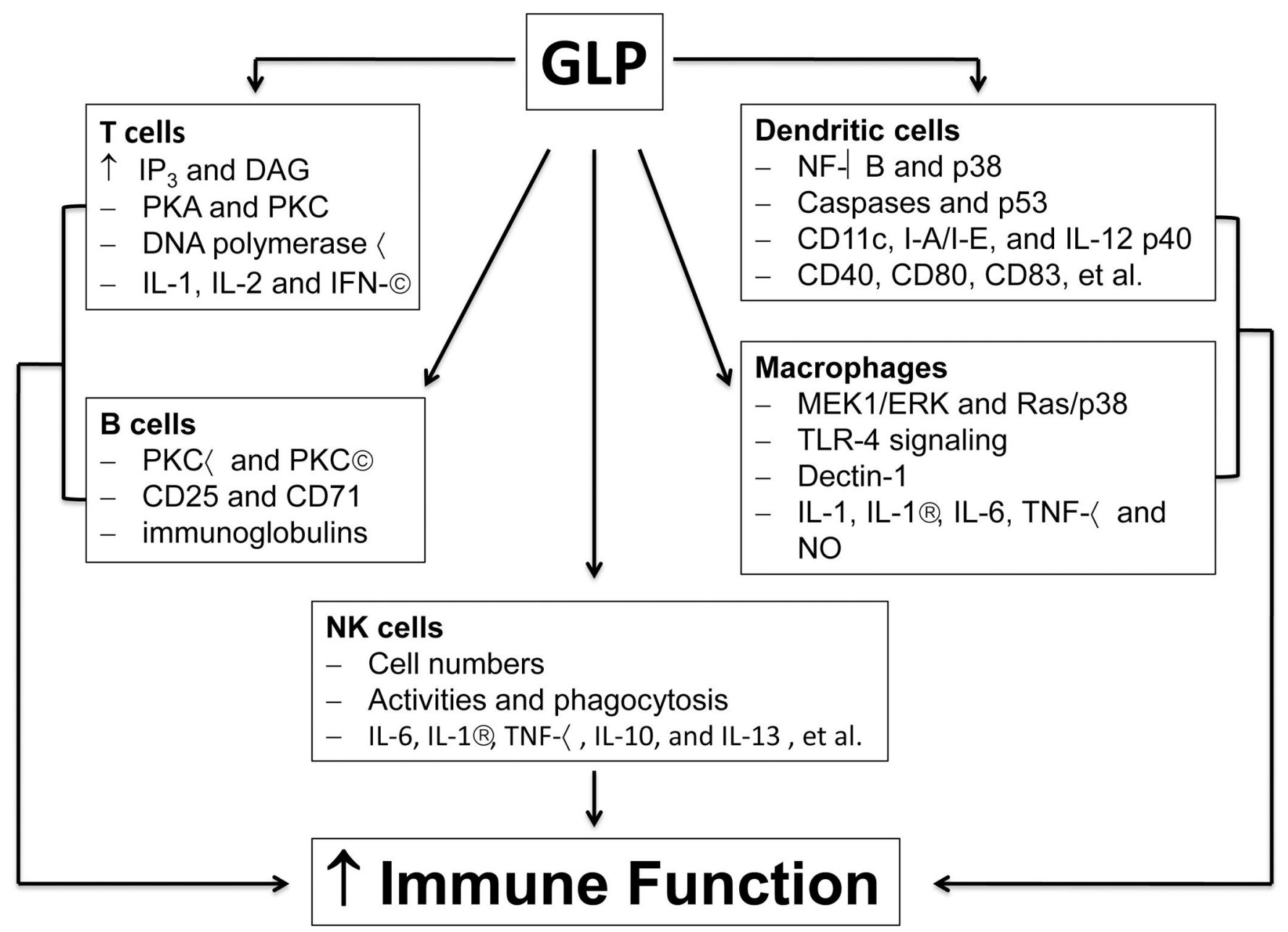

Fig 2.

Mechanisms of immunomodulatory action of Gonaderma lucidium polysaccharides. $\uparrow$ : increasing or activating. 


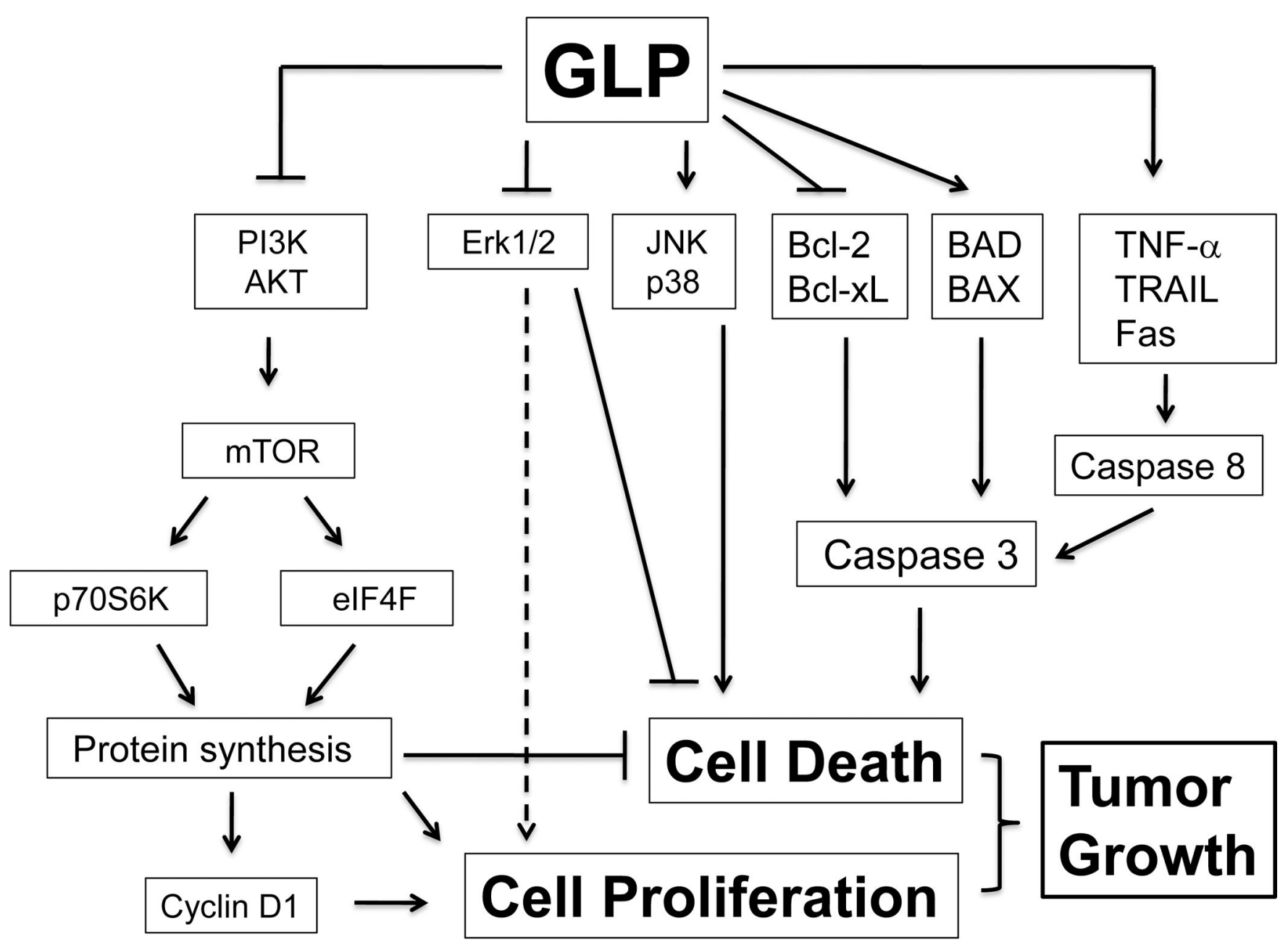

Fig 3.

Signaling pathways involved in anti-proliferative and pro-apoptotic effects of Gonaderma lucidium polysaccharides on tumor cells. Arrows represent activation, whereas bars represent inhibition. 


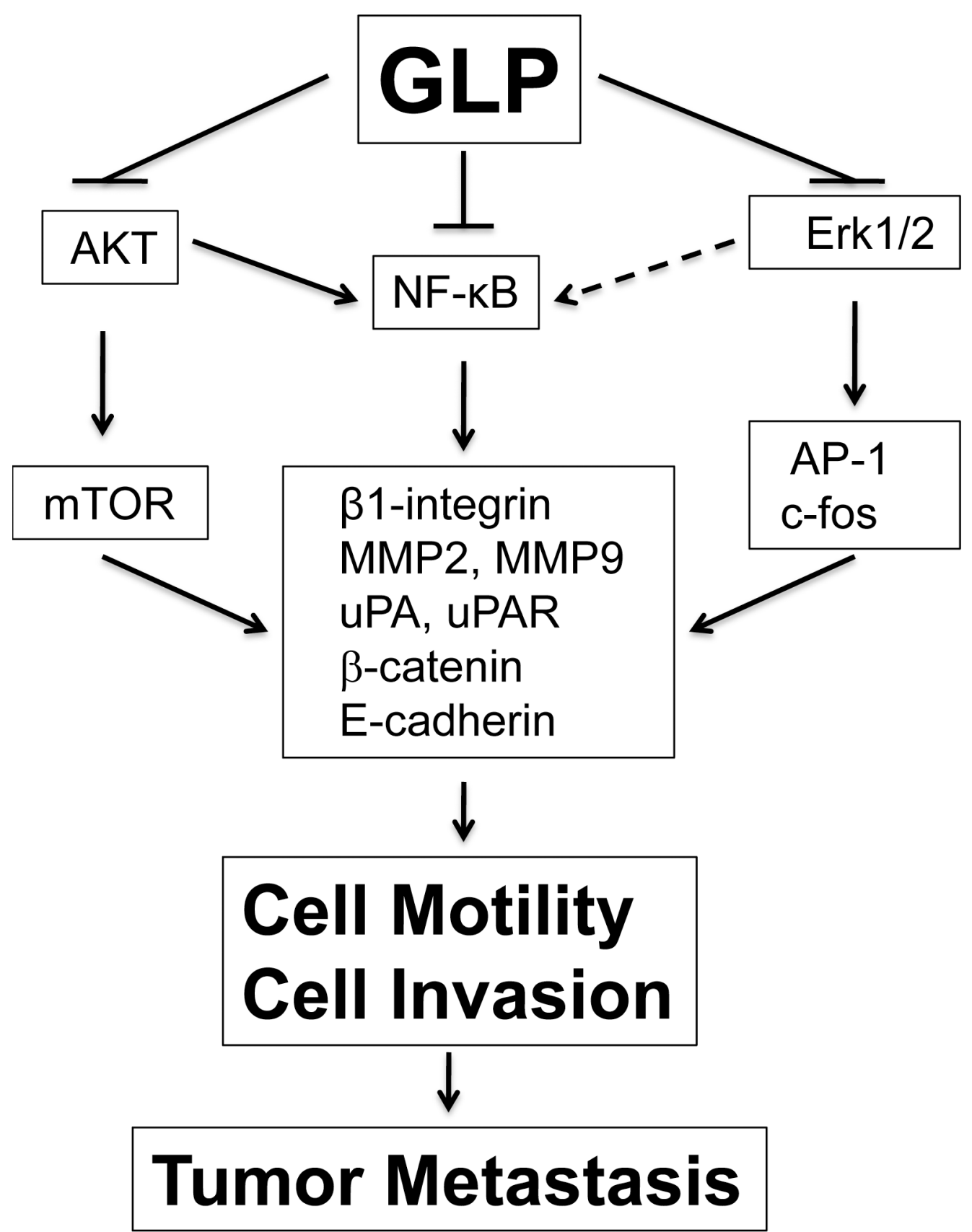

Fig 4.

Signaling pathways involved in anti-metastatic effect of Gonaderma lucidium polysaccharides. Arrows represent activation, whereas bars represent inhibition. 